Syntax Literate: Jurnal Ilmiah Indonesia p-ISSN: 2541-0849

e-ISSN : 2548-1398

Vol. 6, No. 10, Oktober 2021

\title{
TERPAAN PUBLIKASI GREENER DAY PADA AKUN INSTAGRAM @STARBUCKSINDONESIA DAN WOM TERHADAP CITRA MEREK
}

\author{
Ifkaristhy Panaya Purba, Neni Yulianita, Kinkin Yuliaty Subarsa Putri, Poppy \\ Ruliana \\ STIKOM InterStudi, Universitas Islam Bandung, Universitas Negeri Jakarta, STIKOM \\ InterStudi, Indonesia \\ Emal: ifkaristhypanaya@gmail.com,yulianita.neni@gmail.com, \\ dr.herkin@gmail.com, poppyruliana30@gmail.com
}

\begin{abstract}
Abstrak
Industri food and beverage mengalami kenaikan signifikan yang berdampak pada persaingan bisnis yang ketat. Salah satunya adalah Starbucks Indonesia, strateginya dalam memenangkan pasar adalah dengan menciptakan citra merek positif melalui terpaan media publikasi pada akun Instagram @starbucksindonesia. Tujuan studi ini yakni mengetahui apakah terdapat pengaruh dari terpaan publikasi greener day melalui posting instagram pada akun @starbucksindonesia dan word of mouth terhadap citra merek Starbucks Indonesia. Penelitian ini menggunakan pendekatan kuantitatif dengan metode studi kepustakaan, observasi dan kuesioner yang disebarkan kepada 100 responden. Metode analisis yang digunakan adalah uji validitas, uji reliabilitas, $\mathrm{z}$, analisis linear berganda dan uji hipotesis, koefisien determinasi. Hasilnya terdapat pengaruh secara signifikan antara terpaan publisitas (XI) dan WOM (X2) terhadap citra merek (Y) secara masing-masing bertanda positif $(0,289)$ dan $(0,016)$ memiliki nilai signifikan 0,000 yang kurang dari 0,05 . Keduanya juga mempengaruhi citra merek secara bersamaan terbukti dari hasil analisis pada nilai koefisien determinan regresi linear berganda pada tabel di atas diperoleh nilai $\mathrm{R}^{2}$ ) menunjukkan 0,989 atau sebesar $98,9 \%$.
\end{abstract}

Kata Kunci: terpaan publisitas; instagram; world of mouth; citra merek

\section{Abstract}

The food and beverage industry has experienced a significant growth which has an impact on fierce competition. One of them is Starbucks Indonesia, its strategies in winning the market is to create a positive brand image through publicity media exposure to Instagram account @starbucksindonesia. The purpose of this study is to find out whether there is an effect of exposure to publications by greener day via Instagram posts on the @starbucksindonesia account and word of mouth on the brand image of Starbucks Indonesia. This research uses a quantitative approach with literature study methods, observations and questionnaires distributed to 100 respondents. The analytical method used is the validity test, reliability test, classical assumption test, multiple linear analysis and hypothesis testing, the coefficient of determination. The result is that there is a significant effect between publicity exposure $(X I)$ and WOM $(X 2)$ on brand image $(Y)$, respectively, which are

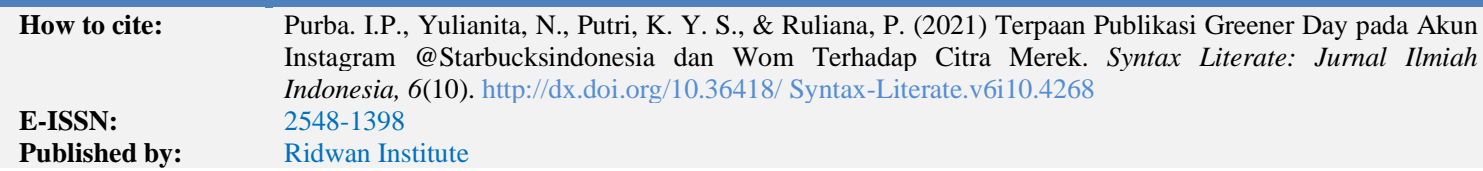


positive (0.289) and (0.016) have a significant value of 0.000 which is less than 0.05. Both also affect the brand image simultaneously as evidenced by the results of the analysis on the coefficient of determinant of multiple linear regression in the table above, the R2 value shows 0.989 or $98.9 \%$.

Keywords: publicity exposure; instagram; word of mouth; brand image

Received: 2021-09-20; Accepted: 2021-10-05; Published: 2021-10-20

\section{Pendahuluan}

Indonesia termasuk ke dalam salah satu pasar layanan makanan terbesar di ASEAN dalam segmen food service menurut Agriculture and Agri-Food Canada melalui Market Access Secretariat Global Analysis Report (Bella, 2018) dengan penjualannya mencapai US\$36,8 pada 2014. Bisnis coffee shop atau kedai kopi menjadi tren lini bisnis yang unggul di Indonesia. Fenomena jajan kopi berkembang pesat di kalangan generasi milenial sebagai gaya hidup dalam bergaul, bukan hanya menikmati kopi. Badan Pusat Statistik mencatat terdapat 2,25 milyar gelas minuman yang berbahan dasarnya ekstrak biji kopi serta setiap hari dikonsumsi di seluruh dunia (Badan Pusat Statistik, 2015). Di Indonesia, konsumsi minuman dengan ekstrak biji kopi di Indonesia diperkirakan akan meningkat pada tiap tahunnya. Hal tersebut disebabkan kopi telah menjadi gaya hidup di kalangan masyarakat. Kedai kopi sering kali dijadikan tempat untuk bertemu, rapat, bahkan untuk belajar sambil menikmati kopi. Dengan demikian, persaingan bisnis kedai kopi pun tidak hanya pada sektor retail atau internasional, namun juga banyak muncul kedai kopi lokal dengan harga lebih murah, dekorasi kedai menarik, dan fasilitas yang menjanjikan.

Penting bagi suatu industri untuk memilih medium yang tepat untuk mengkomunikasikan merek kepada khalayak luas. Medium merupakan sebuah sarana berkomunikasi yang dipakai oleh komunikator pada komunikan guna mencapai target dan efisiensi dalam diseminasi pesan ataupun informasi. Media yang sangat diminati karena memiliki efek signifikan ialah media baru. Menurut (Denis McQuail, 2012), media baru mempunyai akses langsung dan keterhubungan yang tidak terbatas oleh lokasi, cakupannya luas dan tidak terukur karena ditunjang dengan komputer digital berbasis internet.

Produk internet yang diakses oleh publik dengan frekuensi tertinggi yakni media sosial. Salah satu platform yang paling banyak dimanfaatkan para pelaku usaha dalam memasarkan merek usahanya adalah media sosial Instagram. Instagram merupakan platform media sosial berbasis internet dengan fitur photo, video dan caption terhitung dari November 2019 mempunyai jumlah pengguna aktif 61.610 .000 yang berarti 22,6\% penduduk Indonesia (Pertiwi, 2019). Terpaan informasi media sosial berdampak pada publisitas atau pemasaran suatu awareness dan image dari sebuah merek (Putri \& Kurnia, 2016). Selain itu, media sosial dapat menghasilkan respon pengguna aktif internet atau biasa disebut Internet Citizen. 
Penyebaran citra suatu merek dapat juga dilakukan melalui Word Of Mouth atau WOM, merupakan sebuah informasi lisan atau tertulis bahkan elektronik dari individu ke individu lainnya (Kotler, P., \& Keller, 2012). WOM dinilai sebagai jenis komunikasi pemasaran dalam bisnis yang mempunyai keunggulan karena kekuatannya sangat efektif dan persuasif serta tidak memerlukan biaya besar seperti iklan (Oktavianto, 2014). Adanya respon dari Internet Citizen itu sendiri merupakan hasil dari terpaparnya informasi dari media sosial. Berbagai reaksi tersebut dapat berbentuk sebuah testimoni, rekomendasi, atau hanya penyebaran informasi saja. Hasil dari WOM dapat berupa kesan positif atau negatif dari suatu objek. WOM dapat dinilai sebagai salah satu faktor yang membentuk citra merek atau perusahaan itu sendiri (Themba \& Mulala, 2013). Citra yang kuat dan unggul akan menciptakan posisikan merek menjadi yang terbaik di mata khalayak (Hermawan, 2012).

Starbucks Indonesia merupakan salah satu retail kedai kopi dari Amerika Serikat yang menyajikan berbagai varian kreasi minuman kopi dengan mengutamakan keramahan pelayanan dan kenyamanan dekorasi. Citra Starbucks Indonesia dikenal sebagai kedai kopi dengan minuman kopi eksklusif dengan harga mahal. Terlebih pada tahun 2019, MAPB menargetkan penjualan dan laba bersih akan naik sebesar $20 \%$ untuk Starbucks Indonesia (Aldin, 2019). Target tersebut diiringi dengan keputusan Starbucks Indonesia menaikkan harga minuman kopi dan penjualan olahan biji kopi yang dijualnya (Ardhi, 2012). Meskipun demikian, Starbucks Indonesia sangat jarang melakukan aktivitas pemasaran dengan iklan media konvensional seperti televisi, radio, ataupun media yang tercetak, melainkan memfokuskan pada publisitas melalui public relations.

Pada sisi lain, banyak kedai kopi lokal atau start-up kopi yang menjalankan bisnis berkualitas serupa namun harga lebih murah. Kesenjangan harga yang ditawarkan cukup jauh, sebagaimana tertera dalam tabel 1.

Tabel 1

Perbandingan Harga Cappucino

\begin{tabular}{clc}
\hline No. & \multicolumn{1}{c}{ Nama Kedai } & Harga Ukuran Standar \\
\hline 1 & Starbucks & Rp42,000 \\
\hline 2 & Maxx Coffe & Rp31,000 \\
\hline 3 & Fore Coffee & Rp25,000 \\
\hline 4 & Kopi Kenangan & Rp18,000 \\
\hline 5 & Janji Jiwa & Rp18,000 \\
\hline
\end{tabular}

Kiat Starbucks untuk mencapai target dan menarik pelanggan di tengah ketatnya persaingan pasar ialah melalui strategi kampanye peduli lingkungan yakni Starbucks Greener Day. Program tersebut dirancang sebagai kampanye publik yang dilakukan oleh Starbucks Indonesia untuk mengurangi sampah plastik. Starbucks Greener Day dipromosikan melalui akun Instagram @starbucksindonesia. Terpaan dalam akun instagram mampu merangsang berbagai respon dari internet citizen sehingga menciptakan WOM yang berdampak pada citra merek Starbucks Indonesia. Hasil 
positif akan membentuk citra positif merek Starbucks Indonesia dan sebaliknya, citra negatif dapat memengaruhi target yang ingin dicapai. Hal ini menjadi tantangan bagi Starbucks dengan citranya sebagai kopi premium di tengah persaingan pasar kedai kopi lokal yang lebih murah.

Starbucks Greener Day adalah sebuah kampanye publik yang dilakukan oleh Starbucks Indonesia untuk mengurangi sampah plastik. Starbucks Greener Day selalu diperingati setiap hari Kamis di setiap minggunya, di dalam program kampanye ini juga dimanfaatkan oleh pihak Starbucks dalam memberikan potongan harga sebesar $50 \%$ untuk konsumen dengan membawa tumbler Starbucks. Kampanye ini hanya dipublikasikan melalui media digital atau media promosi di sekitar gerai atau pada media promosi yang dimiliki oleh pusat perbelanjaan. Salah satu media digital yang digunakan Starbucks Indonesia dalam memasarkan dan mempublikasikan kampanye Starbucks Greener Day adalah media sosial Instagram. Kampanye yang digalang oleh Starbucks Indonesia yang dipasarkan secara rutin diposting di akun @ starbucksindonesia di setiap minggunya di setiap hari Rabu atau pada hari Kamis. Akun instagram dari @ starbucksindonesia sendiri sudah diikuti oleh 1,200,000 akun instagram dan akan bertambah di setiap detiknya. Kampanye Starbucks Greener Day ditunjukkan dalam salah satu unggahan pada Gambar 1 berikut ini.

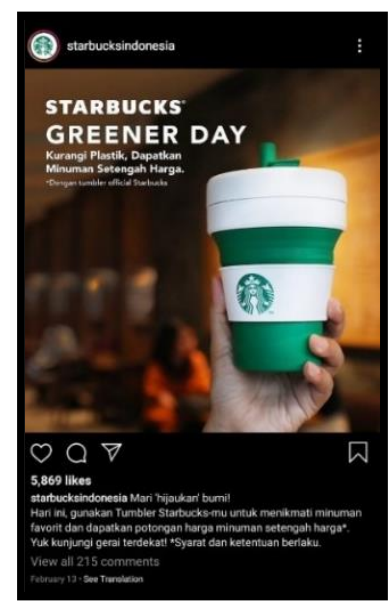

\section{Gambar 1}

Konten Kampanye Starbucks Greener Day di Salah Satu Unggahan pada akun Instagram @starbucks Indonesia

WOM dikenal sebagai proses pertukaran informasi antara individu atau khalayak yang mengandung unsur produk, jasa, atau suatu merek dan dianggap sarana komunikasi yang mempunyai efek signifikan dalam penyebaran informasi (Sharma \& Pandey, 2014). WOM yang terjadi dalam medium jaringan internet seperti media sosial disebut dengan E-WOM. Percakapan dalam media sosial misalnya dilakukan dengan mengulas suatu produk. Semakin kuat E-WOM maka semakin cepatnya individu atau khalayak terpengaruh dalam informasi yang diberikan. Citra merek ialah suatu persepsi yang ada dibenak individu atau khalayak ketika mengingat mengenai suatu merek dari 
produk tertentu (Tjiptono, 2012). Persepsi yang terbentuk atas suatu merek meliputi lambang, nama, istilah, atau desain produk. Semakin kuat ingatan khalayak atas merek, maka semakin baik citra merek tersebut. Empat komponen yang membentuk merek antara lain asosiasi merek, kekuatan dari asosiasi merek, kesukaan masyarakat dari suatu merek, dan keunikan asosiasi merek (Pentury, Sugianto, \& Remiasa, 2019). Citra merek yang unggul dan berbeda dari yang lain akan menandakan kualitas produk baik dan memungkinkan adanya pembelian kembali (Kotler \& Keller, 2012).

Beberapa studi terdahulu dilakukan oleh para peneliti, antara lain studi berjudul "Pengaruh Word of Mouth terhadap Purchase Intention dengan Brand Image dan Perceived Service Quality" oleh (Indra, 2018). Penelitian tersebut menggunakan metode kuantitatif dengan dimensi dari variabel brand image (citra merek) seperti yang digunakan oleh peneliti yaitu strength, favorability, dan uniqueness. Selain itu, penelitian ini menguji hal yang sama yatu pengaruh positif dari Word of Mouth terhadap brand image (citra merek). Hasil dari penelitian tersebut adalah nilai uji t-statistik >1,96 yaitu 17,939 yang menunjukan bahwa Word of Mouth mempunyai pengaruh terhadap brand image (citra merek) dengan Word of Mouth membuat persepsi baik dibenak calon pelanggan KPR bersubsidi.

Adapun studi berjudul "Pengaruh $e-W O M$ di Instagram terhadap destination image di Farmhouse Susu Lembang-Bandung” oleh (Noviyanti, Puspita, \& Firmansyah, 2018) juga telah dilakukan. Penelitian ini menggunakan metode kuantitatif dengan adanya kesamaan indikator pengukur dari variabel Word of Mouth yaitu opini dari khalayak yaitu penilaian positive dan negative valance. Media sosial digunakan sebagai objek penelitian ini. Temuan yang dihasilkan studi ini menunjukan bahwa negative valance tidak terlalu berdampak terhadap destination image. Namun indikator positive valance berpengaruh secara signifikan terhadap destination image.

Merujuk pada uraian latar belakang yang dipaparkan, maka studi ini bertujuan untuk mengetahui pengaruh dari terpaan publikasi greener day melalui unggahan pada akun instagram @starbucksindonesia dan WOM terhadap citra merek Starbucks Indonesia.

\section{Metode Penelitian}

Studi ini menerapkan paradigma positivis dengan pendekatan kuantitatif. Jenis penelitiannya ekplanatif dan metodenya yakni survei. Dalam penelitian ini, peneliti akan mengukur ada atau tidak adanya pengaruh antara publisitas melalui media sosial dan Word of Mouth terhadap dengan citra merek dari Starbucks Indonesia. Populasi dari penelitian ini adalah pengikut dari akun instagram @ starbucksindonesia dengan jumlah 1.200.000 orang. Sampel yang diambil sejumlah 100 orang dari 1.200 .000 akun yang mengikuti@starbucksindonesia dan mengacu pada teknik purposive sampling. Kriteria sampel yang ditetapkan yakni pria dan wanita dengan usia 17-40 tahun, usia dewasa, dapat mengambil keputusan sendiri, dan berdomisili di Jakarta.

Pada studi ini, peneliti menjalankan penghimpunan data melalui kuesioner (angket) sebagai metodenya. Peneliti mengukur indikator dalam penelitian ini dengan 
skala Likert karna dapat mengujur persepsi, pendapat bahkan sikap seseorang dari sebuah fenomena sosial. Pada riset ini terdapat 4 tingkatan dari skala 1 hingga 4, yakni Sangat Tidak Setuju bernilai skor 1, Tidak Setuju bernilai skor 2, Setuju bernilai skor 3, dan Sangat Setuju bernilai skor 4.

Peneliti menerapkan teknik analisis regresi linear berganda untuk menguji hipotesis. Adapun tahapan analisis data antara uji validitas, uji reliabilitas, uji multikolinearitas, uji heteroskedastisitas, uji autokorelasi, uji normalitas, uji T, dan uji F. Guna melihat seberapa besar pengaruh variabel masing-masing terhadap variabel terikat maka dilakukan uji T. Jika Ho $: b_{i}=0$ secara parsialitas maknanya berarti tidak diidentifikasi pengaruh yang positif dan siginifikan dari variabel independen (X1 dan X2) terpaan melalui media baru dan Word of Mouth (WOM) terhadap citra merek yang diposisikan menjadi variabel dependen (Y). Uji F diterapkan guna meninjau kemungkinan seluruh variabel independen membawa pengaruh positif terhadap variabel terikat. Model yang digunakan ialah $\mathrm{b} 1, \mathrm{~b} 2=0$ bermakna secara bersamaan tidak diidentifikasi pengaruh yang positif dari variabel bebas (X1 dan X2) yaitu terpaan melalui media baru dan Word of Mouth (WOM) terhadap citra merek sebagai variabel (Y). Guna menetapkan variabel yang berdominasi tertinggi ditentukan melalui koefisien regresi yang terstandarisasi.

\section{Hasil dan Pembahasan}

\section{A. Hasil Penelitian}

Dalam mengetahui keabsahan dari suatu kuesioner maka digunakan uji validitas. Diistilahkan valid apabila jika nilai $\mathbf{r}_{\text {hitung }}>$ dari $\mathbf{r}_{\text {tabel. }}$. Uji yang dilakukan menunjukkan semua item pertanyaan pada Terpaan Melalui Media Sosial (X1) terdapat sebanyak 31 item pernyataan memiliki nilai $r_{\text {hitung }}>r_{\text {tabel }}(0,196)$ dikatakan "valid". Hasil uji item pertanyaan kuisioner pada variabel Word of Mouth / WOM (X2) diketahui dari 44 item pernyataan kuesioner pada variabel Word of Mouth / WOM (X2) terdapat sebanyak 44 item pernyataan memiliki nilai $\mathrm{r}_{\text {hitung }}>\mathrm{r}_{\text {tabel }}$ $(0,196)$ yang menunjukan semuanya valid. Pada variabel Citra Merek (Y) terdapat sebanyak 9 item pernyataan mengandung nilai $r_{\text {hitung }}>r_{\text {tabel }}(0,196)$ yang menunjukan item pernyataan tersebut dikatakan "valid".

Uji reliabilitas guna mengetahui konsistensi jawaban responden dari dimensi variabel, diterapkan menggunakan Cronbach Alpha. Maka variabel Terpaan Melalui Media Sosial (X1), Word of Mouth / WOM (X2), dan Citra Merek (Y) ditunjukkan dalam Tabel 2 sebagai berikut.

\section{Tabel 2}

Uji Reliabilitas

\begin{tabular}{ccc}
\hline Variabel & Cronbach's Alpha & N of Items \\
\hline $\mathrm{X} 1$ & 0,980 & 31 \\
\hline $\mathrm{X} 2$ & 0,969 & 44 \\
\hline $\mathrm{Y}$ & 0,928 & 9 \\
\hline
\end{tabular}


Merujuk pada tabel 2, diidentifikasi nilai Cronbach's Alpha pada variabel Terpaan Melalui Media Sosial (X1) adalah sebesar 0,980 yang berarti variabel Terpaan Melalui Media Sosial (X1) sangat reliabel. Lalu pada Variabel Word of Mouth / WOM (X2) didapat nilai Cronbach's Alpha senilai 0,969 yang berarti variabel X2 sangat reliabel. Pada Variabel Citra Merek (Y) didapat nilai Cronbach's Alpha senilai 0,928 yang berarti Varuabel Y sangat reliabel.

Analisis distribusi frekuensi dilakukan untuk melihat persentase frekuensi pada masing-masing pertanyaan yang terdapat dalam masing-masing variabel kuesioner sebagaimana ditunjukkan tabel 3.

Tabel 3

Saya Melihat Postingan Instagram Akun@starbucksindonesia Minimal 3 Kali dalam Satu Minggu

\begin{tabular}{ccccc}
\hline & Frekuensi & Persen $(\%)$ & Valid Persentase & Kumulatif Persentase \\
\hline Sangat Tidak Setuju & 8 & 8.0 & 8.0 & 8.0 \\
\hline Tidak Setuju & 8 & 8.0 & 8.0 & 16.0 \\
\hline Setuju & 12 & 12.0 & 12.0 & 28.0 \\
\hline Sangat Setuju & 72 & 72.0 & 72.0 & 100.0 \\
\hline Total & 100 & 100.0 & 100.0 & \\
\hline
\end{tabular}

Terdapat sebanyak 72 responden yang menjawab Sangat Setuju atas pernyataan 'Saya Melihat Postingan Instagram Akun Instagram @Starbucksindonesia Minimal 3 Kali dalam Satu Minggu'. Juga terhadap pernyataan 'Saya Melihat Postingan Instagram Akun @Starbucksindonesia Mengenai Greener Day Minimal 2 Kali dalam Satu Minggu' memperoleh respon Sangat Setuju sebanyak $66 \%$ atau 66 responden. Distribusi frekuensi variabel Terpaan Melalui Media Sosial (X1) dengan skala Likert menunjukkan bahwa mayoritas responden menjawab Sangat Setuju yang berarti bahwa responden sering mengakses dan melihat unggahan di akun@starbucksindonesia.

Tabel 4

Saya Pernah Mengirimkan Postingan dari Akun Starbucks Indonesia mengenai Greener Day kepada Akun Instagram Lainnya Frekuensi Persen (\%) Valid Persentase Kumulatif Persentase

\begin{tabular}{ccccc}
\hline Sangat Tidak Setuju & 7 & 7.0 & 7.0 & 7.0 \\
\hline Tidak Setuju & 20 & 20.0 & 20.0 & 27.0 \\
\hline Setuju & 10 & 10.0 & 10.0 & 37.0 \\
\hline Sangat Setuju & 63 & 63.0 & 63.0 & 100.0 \\
\hline Total & 100 & 100.0 & 100.0 & \\
\hline
\end{tabular}

Pada distribusi frekuensi variabel Word of Mouth sebagaimana ditunjukkan Tabel 4 menunjukkan bahwa persentase responden menjawab Sangat Setuju bernilai dominan. Sebanyak 63 dari 100 responden menjawab Sangat Setuju 
terhadap pernyataan 'Saya Pernah Mengirimkan Postingan Mengenai Greener Day dari@Starbucksindonesia ke Akun Instagram Lainnya'. Hasil tersebut mengimplikasikan bahwa responden berfrekuensi tinggi dalam berinteraksi dengan akun Instagram @starbucksindonesia, seperti membagikan unggahan ke akun instagram lainnya melalui Direct Message, Insta Story, menyukai unggahan Greener Day di akun Starbucks Indonesia, dan berkomentar. Pada variabel ini juga menunjukkan bahwa responden pernah berpartisipasi dalam komunikasi WOM tentang unggahan akun @ starbucksindonesia.

\section{Tabel 5}

Minuman Olahan Kopi Dengan Merek Starbucks Indonesia Konsisten Menghasilkan Produk Berkualitas dan Layanan Prima

\begin{tabular}{ccccc}
\hline \multicolumn{5}{c}{ Konsisten Menghasilkan Produk Berkualitas dan Layanan Prima } \\
\hline Sangat Tidak Setuju & 5 & 5.0 & 5.0 & 5.0 \\
\hline Tidak Setuju & 11 & 11.0 & 11.0 & 16.0 \\
\hline Setuju & 18 & 18.0 & 18.0 & 34.0 \\
\hline Sangat Setuju & 66 & 66.0 & 66.0 & 100.0 \\
\hline Total & 100 & 100.0 & 100.0 & \\
\hline
\end{tabular}

Distribusi frekuensi variabel Citra Merek sebagaimana disajikan pada Tabel 5 menghasilkan bahwa responden Sangat Setuju atas pernyataan yang menyatakan bahwa merek Starbucks Indonesia konsisten dengan kualitas dan layanannya, cocok untuk masyarakat Indonesia, berkualitas terbaik, layak, merek yang peduli lingkungan, dan menginspirasi masyarakat untuk peduli lingkungan. Sebanyak 66 dari 100 responden merespon Sangat Setuju terhadap pernyataan 'Minuman Olahan Kopi dengan Merek Starbucks Indonesia Konsisten Menghasilkan Produk Berkualitas dan Layanan Prima'. Pernyataan terkait "Minuman olahan kopi dari kedai kopi Starbucks Indonesia bukan hanya sebuah minuman kopi tapi menginspirasi masyarakat Indomesia untuk peduli lingkungan" mendapatkan respon terbanyak dari responden dengan pernyataan "Sangat Setuju" menujukan hasil persentase $71 \%$ yang berarti terdiri dari 71 responden.

Guna mengidentifikasikan pengaruh antara variabel Media Sosial (X1) dan Word of Mouth (X2) terhadap variabel Citra Merek (Y) peneliti menerapkan analisis regresi linear berganda yang mencakup analisis model regresi, uji simultan (Uji F), uji parsial (uji T), dan koefisien determinan yang ditunjukkan Tabel 6 berikut. 
Tabel 6

Analisis Model Regresi

\begin{tabular}{|c|c|c|c|c|c|c|}
\hline \multirow{2}{*}{\multicolumn{2}{|c|}{ Model }} & \multicolumn{2}{|c|}{ Unstandardized Coefficients } & \multirow{2}{*}{$\begin{array}{c}\text { Standardized Coefficients } \\
\text { Beta } \\
\end{array}$} & \multirow{2}{*}{$\mathbf{t}$} & \multirow{2}{*}{ iig. } \\
\hline & & B & Std. Error & & & \\
\hline & (Constant) & -1.092 & .412 & & -2.653 & .009 \\
\hline \multirow[t]{2}{*}{1} & X1.Total & 0.289 & .004 & .955 & 71.773 & .000 \\
\hline & X2.Total & 0.016 & .003 & .065 & 4.870 & .000 \\
\hline
\end{tabular}

Berdasarkan tabel 6 regresi linear berganda yang dipaparkan, diperoleh informasi bahwa nilai Citra Merek senilai -1,092 satuan yang berarti variabel Terpaan Melalui Media Sosial (X1) dan Word of Mouth / WOM (X2) bernilai nol. Nilai koefisien X1 senilai 0,289 mengimplikasikan bahwa jika variabel Terpaan Melalui Media Sosial (X1) memberikan pengaruh positif terhadap variabel Citra Merek (Y) karena memiliki nilai koefisien bertanda positif. Hal itu menunjukkan jika variabel Terpaan Melalui Media Sosial (X1) meningkat satu satuan, maka Citra Merek akan meningkat senilai 0,289 Satuan. Namun pada setiap penurunan 1 satuan Terpaan Melalui Media Sosial (X1) maka akan menurunkan Citra Merek (Y) sebesar 0,289 satuan. Nilai koefisien X2 sebesar 0,016 mengimplikasikan bahwa jika variabel Word Of Mouth / WOM (X2) memberikan pengaruh positif terhadap variabel Citra Merek (Y) karena memiliki nilai koefisien bertanda positif. Hal itu menujukkan jika variabel Word Of Mouth / WOM (X2) naik 1 satuan dengan demikian akan menaikkan Citra Merek (Y) sejumlah 0,016 satuan. Sebaliknya, setiap penurunan 1 satuan Variabel variabel Word Of Mouth / WOM (X2) maka akan mnurunkan Variabel Citra Merek (Y) sebesar 0,016 satuan.

Untuk mengetahui kekuatan dari dimensi dilakukan analisis untuk mengetahui besar pengaruh masing-masing dimensi terhadap variabel citra merek (Y) dengan menggunakan rumus perhitungan sumbangan efektif yaitu dengan analisis korelasi dan analisis regresi dengan masing-masing dimensi sebagai variabel independent. Sehingga menghasilkan perhitungan sebagai berikut:

\section{$S E(X) \%=$ Beta Standardized ${ }_{x} \times r_{x y} \times 100 \%$}

\section{Tabel 7}

Analisis Kekuatan Dimensi

\begin{tabular}{cccc}
\hline Variabel & $\begin{array}{c}\text { Standardize } \\
\text { Coefficient Beta }\end{array}$ & $\begin{array}{c}\text { Pearson } \\
\text { Correlation }\end{array}$ & SE \\
\hline X1_Frekuensi & 3,214 & 0,215 & $69,10 \%$ \\
\hline X1_Durasi & $|-1,177|$ & 0,186 & $21,89 \%$ \\
\hline X1_Atensi & $|-1,808|$ & 0,179 & $32,36 \%$ \\
\hline X2_Intensity & $|-0,453|$ & 0,266 & $12,05 \%$ \\
\hline $\begin{array}{c}\text { X2_Positive } \\
\text { Valance }\end{array}$ & $|-0,057|$ & 0,232 & $1,32 \%$ \\
\hline $\begin{array}{c}\text { X2_Negative } \\
\text { Valance }\end{array}$ & $|-0,790|$ & 0,257 & $20,30 \%$ \\
\hline X2_Content & 1,337 & 0,262 & $35,03 \%$ \\
\hline
\end{tabular}


Tabel 7 menunjukkan bahwa dimensi frekuensi memberikan pengaruh sebesar 69,10\% terhadap citra merek (Y). Dimensi durasi memberikan pengaruh sebesar 21,89\% terhadap citra merek (Y). Lalu dimensi atensi memiliki pengaruh sebesar 32,36\% terhadap variabel citra merek (Y). Selanjutnya dimensi intensity memberikan pengaruh sebesar $12,05 \%$ terhadap citra merek (Y) Dimensi positive valance memberikan pengaruh sebesar $1,32 \%$ terhadap citra merek (Y). Dimensi negative valance memberikan pengaruh sebesar $20,30 \%$ terhadap citra merek (Y). Serta variabel content memberikan pengaruh sebear 35,03\% terhadap citra merek (Y).

Peneliti juga meninjau terpaan dari Media Sosial (XI) dan Word of Mouth (X2) secara serempak berdampak pada citra merek (Y) maka peneliti menggunakan Analisis uji simultan atau uji F. Jika nilai signifikansinya $<0,05$ dengan demikian didapatkan kesimpulan bahwa variabel independen berpengaruh secara bersamasama terhadap variabel $\mathrm{Y}$. Hasilnya yang didapat ialah sebagaimana Tabel 8 berikut.

\section{Tabel 8}

\section{Uji Simultan Regresi Linear Berganda}

\begin{tabular}{|c|c|c|c|c|c|c|c|}
\hline Model & Sum of Squares & $\mathrm{df}$ & Mean & Square & $\mathrm{F}$ & Sig. & \\
\hline 1 Regression & 4035.278 & & 2 & 2017.639 & & $4.247 \mathrm{E} 3$ & 0,000 \\
\hline Residual & 46.082 & & 97 & .475 & & & \\
\hline Total & 4081.360 & & 99 & & & & \\
\hline
\end{tabular}

Merujuk pada analisis hasil pada tabel yang dipaparkan diidentifikasi bahwa angka signifikan pada uji simultan (Uji F) regresi linear berganda adalah senilai 0,000 yang berimplikasi kurang dari 0,05 . Kesimpulannya bahwa variabel Terpaan Melalui Media Sosial (X1) dan Word of Mouth / WOM (X2) keduanya dengan bersama berpengaruh signifikan terhadap Variabel Citra Merek (Y).

Dalam mencari tahu pengaruh masing-masing pada variabel independen (X) pada variabel dependen (Y) maka analisis uji parsial (uji T) dilakukan. Hasil analisis uji parsial adalah pada Tabel 9 sebagai berikut.

Tabel 9

Uji T Regresi Linear Berganda

\begin{tabular}{|c|c|c|c|c|c|c|}
\hline \multirow{2}{*}{\multicolumn{2}{|c|}{ Model }} & \multicolumn{2}{|c|}{$\begin{array}{c}\text { Unstandardized } \\
\text { Coefficients } \\
\end{array}$} & \multirow{2}{*}{$\begin{array}{c}\begin{array}{c}\text { Standardized } \\
\text { Coefficients }\end{array} \\
\text { Beta }\end{array}$} & \multirow[t]{2}{*}{$\mathbf{T}$} & \multirow[t]{2}{*}{ Sig, } \\
\hline & & $\mathrm{B}$ & $\begin{array}{l}\text { Std, } \\
\text { Error }\end{array}$ & & & \\
\hline 1 & (Constant) & $-1,092$ & .412 & & $-2,653$ & 0,009 \\
\hline & $\begin{array}{l}\text { Terpaan Melalui } \\
\text { Media Sosial (X1) }\end{array}$ & 0,289 & ,004 & 0,955 & 71,773 & 0,000 \\
\hline & $\begin{array}{l}\text { Word of Mouth I } \\
\text { WOM (X2) }\end{array}$ & 0,016 & ,003 & 0,065 & 4,870 & 0,000 \\
\hline
\end{tabular}


Berdasarkan pada tabel 9 diketahui bahwa pada variabel Terpaan Melalui Media Sosial (X1) didapatkan nilai signifikansinya senilai 0,000 dengan demikian kurang dari 0,05. Sehingga didapatkan keputusan bahwa Ha diterima dan kesimpulan bahwa terdapat pengaruh signifikan dari terpaan publikasi greener day melalui posting instagram pada akun@starbucksindonesia terhadap citra merek Starbucks Indonesia.

Ho: Tidak menunjukan adanya pengaruh dari Word of Mouth terhadap citra merek Starbucks Indonesia.

Ha: Terdapat pengaruh dari Word of Mouth terhadap citra merek Starbucks Indonesia.

Pada variabel Word of Mouth / WOM (X2) didapatkan nilai signifikansinya senilai 0,000 yang berarti kurang dari 0,05. Dengan demikian didapatkan kesimpulan bahwa terdapat pengaruh signifikan dari Word of Mouth terhadap citra merek Starbucks Indonesia.

Dalam mengetahui kekuatan sebuah variabel independen maka uji koefisien determinasi $\left(\mathrm{R}^{2}\right)$ dilakukan. Semakin tinggi nilai koefisien determinan maka semakin baik model regresi dalam menjelaskan kondisi yang sebenarnya. Hasil yang didapatkan adalah dalam Tabel 10 sebagai berikut.

Tabel 10

Uji Koefisien Determinasi Regresi Linear Berganda

\begin{tabular}{lll}
\hline $\begin{array}{l}\text { Mode } \\
1\end{array}$ & $\mathrm{R}$ & $\mathrm{R}$ Square \\
\hline 1 & 0,994 & 0,989 \\
\hline
\end{tabular}

Hasil analisis pada tabel yang dimaksud menunjukan nilai $R$ Square $\left(\mathrm{R}^{2}\right)$ senilai 0,989. Hal ini berarti bahwa Variabel Terpaan Melalui Media Sosial (X1) dan Word of Mouth / WOM (X2) memberikan pengaruh terhadap variabel Citra Merek (Y) sebesar 98,9\%. Sementara sejumlah sisanya yakni 1,1\% (100\%-98,9\%. $=1,1 \%$ ) yang tidak terjelaskan dalam penelitian yang dilakukan peneliti.

\section{B. Pembahasan}

\section{Pengaruh Variabel Terpaan Melalui Media Baru (X1) Terhadap Citra Merek (Y)}

Terpaan melalui media baru adalah sebuah kondisi di mana individu atau khalayak diterpa informasi dari media baru dengan jangkauan global melalui jaringan atau koneksi internet (D. McQuail, 2012). McQuail menambahkan bahwa media baru merupakan sebuah media komunikasi dengan bentuk konten dan bersifat sangat fleksibel sehingga sangat cepat dalam menyampaikan informasi serta mempunyai kemampuan untuk melakukan interaksi antara komunikator dan komunikan. 
Pada penelitian ini didapatkan kesimpulan bahwa Variabel Terpaan Melalui Media Baru (X1) memberikan pengaruh yang positif dan signifikan terhadap Citra Merek (Y). Hal itu dikarenakan nilai koefisien Variabel Terpaan Melalui Media Baru (X1) bertanda positif $(0,289)$ dan memiliki nilai signifikan 0,000 yang kurang dari 0,05. Berdasarkan variabel Terpaan Melalui Media Baru (X1) diketahui bahwa dimensi frekuensi memberikan pengaruh paling besar dan dimensi durasi memberikan pengaruh paling rendah terhadap citra merek.

Penelitian yang dijalankan oleh (Kevin \& Sari, 2019) juga menunjukan kesejalanan dengan penelitian ini bahwa terpaan media memberikan pengaruh signifikan terhadap brand image. Dalam penelitian yang dilakukan oleh Rustono dan Denise (2018), variabel terpaan media melalui posting instagram bahkan berpengaruh terhadap ekuitas merek yang merupakan besaran dari citra merek, pengaruh cukup besar yaitu 21\%. Media sosial yang berpengaruh cukup besar terhadap citra merek juga memperkuat adanya ekuitas merek. Disimpulkan dalam penelitian Soewandi (2015) jika citra merek yang dibentuk media social dihilangkan maka ekuitas merek melemah.

\section{Pengaruh Variabel Word Of Mouth / WOM (X2) Terhadap Citra Merek (Y)}

WOM dikenal sebagai suatu proses dari pertukaran informasi atau percakapan antara individu atau khalayak di mana di dalamnya terdapat unsur produk, jasa, atau merek tertentu, hingga saat ini WOM dianggap sarana komunikasi yang mempunyai efek signifikan dalam penyebaran informasi (Sharma \& Pandey, 2014).

Pada penelitian ini didapatkan kesimpulan bahwa Variabel Word Of Mouth (X2) memberikan pengaruh yang positif dan signifikan terhadap Citra Merek (Y). Hal itu dikarenakan nilai koefisien Variabel Word Of Mouth (X2) bertanda positif $(0,016)$ dan memiliki nilai signifikan 0,000 yang tidak melebih 0,05. Berdasarkan Variabel Word of Mouth (WOM) diketahui bahwa dimensi content memberikan pengaruh paling besar dan dimensi positive valance memberikan pengaruh paling rendah terhadap citra merek. Dimensi positive valance juga pernah diuji dalam penelitian dari (Noviyanti et al., 2018) serta penelitian dari Wirianti, Zalvina, dan Rusfian (2017) juga membuktikan bahwa dimensi positive valance berpengaruh terhadap variabel destination image selain citra merek.

Peneltitian dari Kartika \& Piranti (2016) yang menyatakan bahwa terdapat yang sama dengan peneltian yang dilakukan oleh peneliti menunjukan adanya pengaruh sebesar 1,66\% antara variabel e-WOM dan citra merek Starbucks Indonesia. Bahkan dalam penelitian yang dilakukan oleh (Indra, 2018) dan (Chai, Ueland, \& Phiri, 2018), variabel citra merek digunakan sebagai variabel intervening untuk variabel perceived service menunjukan uji $\mathrm{t}$ - statistik $>1,96$ yaitu 17,939 yang berarti bahwa Word of Mouth mempunyai pengaruh terhadap brand image (citra merek) dengan Word of Mouth membuat persepsi baik dibenak calon pelanggan KPR bersubsidi. Citra merek juga digunakan sebagai 
variabel intervening pada penelitian (Ruhamak \& Rahayu, 2016) dan penelitian dari Putu Puri Cynthiadewi dan Jurry Hatammimi (2014) terhadap pengaruh Word of Mouth kepada purchase intention juga menghasilkan hasil yang sama membawa dampak sebesar 46,4\%.

\section{Pengaruh Variabel Terpaan Melalui Media Baru (X1) dan Variabel Word Of Mouth / WOM (X2) Terhadap Citra Merek (Y)}

Citra Merek merupakan sebuah impresi atau persepsi perihal merek yang oleh suatu asosiasi ingin direfleksikan dalam ingatan dan citra yang kuat dan unggul akan menciptakan posisi merek menjadi yang terbaik di mata khalayak (Hermawan, 2012). Pada penelitian ini hasil analisis pada nilai koefisien determinan regresi linear berganda menunjukan nilai $R$ Square $\left(\mathrm{R}^{2}\right)$ senilai 0,989. Hal membuktikan bahwa Variabel Terpaan Melalui Media Sosial (X1) dan Word of Mouth / WOM (X2) memberikan pengaruh terhadap variabel Citra Merek (Y) sebesar 98,9\%. Hasil studi ini sejalan dengan penelitian terdahulu dari (Tobing, 2014) dan (Triyandra \& Ratnasari, 2016) yang mengkonklusikan adanya pengaruh yang signifikan antara variabel Terpaan Media Sosial (XI) dan Word of Mouth/ WOM (X2) terhadap Citra Merek (Y).

\section{Kesimpulan}

Merujuk pada hasil analisis data yang dijabarkan, maka kesimpulan yang dapat ditarik yakni terdapat pengaruh signifikan dan positif dari terpaan publikasi greener day melalui posting instagram pada akun @starbucksindonesia terhadap citra merek Starbucks Indonesia terbukti dengan adanya nilai koefisien Variabel Terpaan Melalui Media Baru (X1) bertanda positif $(0,289)$ dan memiliki nilai signifikan 0,000 yang kurang dari 0,05. Terdapat pengaruh signifikan dan positif dari Word of Mouth terhadap citra merek Starbucks Indonesia terbukti dengan adanya nilai koefisien Variabel Word Of Mouth (X2) memberikan pengaruh yang positif dan signifikan terhadap Citra Merek (Y). Hal itu dikarenakan nilai koefisien Variabel Word Of Mouth (X2) bertanda positif $(0,016)$ dan memiliki nilai signifikan 0,000 yang kurang dari 0,05 . Terdapat pengaruh signifikan terpaan publikasi greener day melalui posting instagram pada akun @ starbucksindonesia dan Word of Mouth terhadap citra merek Starbucks Indonesia. Terbukti dari hasil analisis pada nilai koefisien determinan regresi linear berganda pada tabel di atas diperoleh nilai R Square (R2) sebesar 0,989. Hal ini berarti bahwa Variabel Terpaan Melalui Media Sosial (X1) dan Word of Mouth / WOM (X2) memberikan pengaruh terhadap variabel Citra Merek (Y) sebesar 98,9\%. Sedangkan sisanya senilai $1,1 \%(100 \%-98,9 \%$. = 1,1\%) dijelaskan oleh variabel-variabel lain yang tidak diteliti dalam penelitian ini.

Pada penelitian ini juga menemukan bahwa dimensi frekuensi dari Variabel Terpaan Melalui Media Sosial (X1) memberikan pengaruh paling besar dan dimensi durasi memberikan pengaruh paling rendah terhadap citra merek. Sedangkan berdasarkan Variabel Word of Mouth (X2) diketahui bahwa dimensi content memberikan pengaruh paling besar dan dimensi positive valance memberikan pengaruh 
paling rendah terhadap citra merek. Penelitian ini juga menunjukan bahwa kini media sosial juga bermanfaat bagi perusahaan dalam membentuk citra merek dan dalam pemanfaatannya juga dapat terjadi komunikasi 2 arah yang membentuk Word of Mouth yang sangat berguna bagi perusahaan dalam melakukan monitoring crisis atau respon secara langsung seperti penelitian yang dilakukan oleh Pienrasi (2015). Dalam penelitian Suryani (2014) didapatkan hasil bahwa media sosial sudah menjadi gelombang baru di mana media sosial dapat memasarkan dan memperkenalkan produk dan potensi lokal. 
Ifkaristhy Panaya Purba, Neni Yulianita, Kinkin Yuliaty Subarsa Putri, Poppy Ruliana

\section{BIBLIOGRAFI}

Aldin, I. U. (2019). Ekspansi Gerai Baru Starbucks, MAPB Targetkan Penjualan Tumbuh $20 \%$.

Ardhi, R. (2012). Starbucks Coffee Naikkan Harga Jual Minuman Kopi.

Badan Pusat Statistik. (2015). Statistik Kopi Indonesia 2015. Jakarta. Google Scholar

Bella, A. (2018). Mencicip Bisnis Restoran Indonesia di 2019. Google Scholar

Chai, C.-L., Ueland, K., \& Phiri, T. (2018). The use of human capital and limitations of social capital in advancing economic security among immigrant women living in central Alberta, Canada. Social Sciences, 7(11), 220. Google Scholar

Hermawan, A. (2012). Komunikasi Pemasaran. Jakarta: Erlangga. Google Scholar

Indra, C. (2018). Pengaruh Word Of Mouth Terhadap Purchase Intention dengan Brand Image Dan Perceived Service Quality Sebagai Variabel Intervening Pada Program KPR Bersubsidi di Surabaya. Jurnal Manajemen Pemasaran, 12(1), 1-9. Google Scholar

Kartika, C., \& Piranti, D. (2016). Pengaruh Electronic Word of Mouth (EWOM) Twitter@ batikair terhadap Brand Image. Jurnal Visi Komunikasi, 14(1), 104-116. Google Scholar

Kevin, D., \& Sari, W. P. (2019). Pengaruh Terpaan Media Online Terhadap Brand Image Kini Capsule. Prologia, 2(2), 291. https://doi.org/10.24912/pr.v2i2.3590. Google Scholar

Kotler, P., \& Keller, K. (2012). Manajemen Pemasaran (12th ed.). Jakarta: Erlangga, Jakarta. Google Scholar

Kotler, P., \& Keller, K. (2012). Manajemen Pemasaran (12th ed.). Jakarta: Erlangga. Google Scholar

McQuail, D. (2012). Teori Komunikasi Massa. Jakarta: Salemba Humanika. Google Scholar

McQuail, Denis. (2012). Teori Komunikasi Massa 2, trans. by Putri Iva Izzati. Jakarta: Salemba Humanika. Google Scholar

Noviyanti, M., Puspita, N., \& Firmansyah, R. (2018). Pengaruh Electronic Word of Mouth (E-Wom) di Instagram terhadap Destination Image di Farmhouse Susu Lembang, Bandung. Journal of Tourism Destination and Attraction, 6(2), 30-43. Google Scholar 
Oktavianto, Y. (2014). Pengaruh Word of Mouth Terhadap Keputusan Pembelian Konsumen Pada Usaha Mie Ayam Pak Agus di kota Batu. Manajemen Bisnis, 3(1). Google Scholar

Pentury, L. V., Sugianto, M., \& Remiasa, M. (2019). Pengaruh e-Wom terhadao Brand Image dan Purchase Intention pada Hotel Bintang Tiga di Bali. Jurnal Manajemen Perhotelan, 5(1), 26-35. Google Scholar

Pertiwi, W. K. (2019). Facebook Jadi Medsos Paling Digemari di Indonesia. Google Scholar

Putri, Y. M., \& Kurnia, K. (2016). Pengaruh Modal Intelektual Terhadap Profitabilitas Dan Produktivitas Perusahaan Dalam Index LQ45. Jurnal Ilmu Dan Riset Akuntansi (JIRA), 5(3). Google Scholar

Ruhamak, M. D., \& Rahayu, B. (2016). Pengaruh word of mouth terhadap purchase intention melalui brand image pada Lembaga kursus Bahasa inggris Dynamic English Course Pare. EKONIKA Jurnal Ekonomi Universitas Kadiri, 1(2). Google Scholar

Sharma, R., \& Pandey, T. (2014). The impact of electronic word-of-mouth in the distribution of digital goods. Webology, 8(1). Google Scholar

Themba, G., \& Mulala, M. (2013). Brand Related E-Wom and Its Effect on Purchase Decision: an Empirical Study of University of Botswana Students. International Journal of Business and Management, 8(8), 31-40. Google Scholar

Tjiptono, F. (2012). Strategi Pemasaran. Yogyakarta: Penerbit Andi. Google Scholar

Tobing, M. M. (2014). Pengembangan Pasar dan Informasi Pariwisata Indonesia melalui Word of Mouth, Media Sosial, dan Iklan Virtual dalam meningkatkan Wawasan Nasional Pemuda. Prosiding Konferensi Nasional Komunikasi Ikatan Sarjana Komunikasi Indonesia. ISKI. Google Scholar

Triyandra, F., \& Ratnasari, A. (2016). Pemanfaatan New Media dalam Pemasaran Jasa Go-Jek Indonesia. Prosiding Manajemen Komunikasi, 2(1), 77-82. Google Scholar

\section{Copyright holder:}

Ifkaristhy Panaya Purba, Neni Yulianita, Kinkin Yuliaty Subarsa Putri, Poppy Ruliana (2021)

First publication right:

Syntax Literate: Jurnal Ilmiah Indonesia

This article is licensed under:

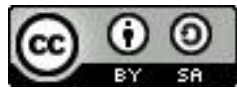

